\title{
LOOKING FOR ALTERNATIVE ONLINE PROMOTION STRATEGY IN VIRTUAL STORE BALERINA BEAUTY SHOP: AN APPLICATION OF ANALYTIC HIERARCHY PROCESS
}

\author{
Fatimah Abdillah \\ Management Department, Sekolah Tinggi Ilmu Ekonomi Pandu Madania \\ abdillah.fatimah@yahoo.com
}

\begin{abstract}
Technology through the internet changes human lifestyle and culture. Ease access to the internet is major support for developing the e-commerce industry. However, in some online companies, not only the internet but also other supporting factors are needed to grow, such as alternative marketing strategies. In the case of Balerina beauty shop, the decreasing number of its visitors for months became the main concern. The company chooses promotional focus as the strategy to deal with visitor problems. Previous research in e-business and analytical hierarchy processes (AHP) issues have not been a concern to promotion strategy, so this study aims to explore the application of analytical hierarchy processes (AHP) in virtual stores and find elements that support online promotion strategies. This study uses a qualitative and quantitative approach. The results of the study indicate that the company has implemented an online promotion strategy such as web promotion with the CPC system, price discounts, social networking systems, smartphone applications, and online group discussions. Actors who play a main role in the company when making strategic decisions are directors, marketing managers, and IT departments. The marketing strategy of the company purposes to increase sales, consumers' awareness, competition, and information dissemination. AHP results show that alternative strategies for the progress of the company, based on priority ranking, are markets, search engine optimization, web advertising, and direct mail. For further development in performance, giving priority to the development of IT skills can be applied.
\end{abstract}

Keywords: Online promotion strategy, alternative strategy, virtual store-front, analytic hierarchy process $(\mathrm{AHP})$

\section{Introduction}

The Internet as a product of technology and information development has become an important part of human life including in the economic sector. It is a computer network that connects people globally. Therefore, it can also be called a natural network (Sibero, 2011). As part of supporting positive economic growth, marketing should engage with the Internet. Promotion as a marketing activity requires the right strategy to achieve corporate goals including the use of the Internet in its strategy development. Marketing as a set of activities that are linked to the purpose of introducing, communicating, disseminating, promoting, and adjusting prices of products and services, attempt to bring satisfaction and benefits to customers (Cravens, D. W., Piercy, N. F., \& Baldauf, 2009; Kotler \& Armstrong, 2008).

Business activities run by Internet users are known as e-commerce. This facilitates interaction between consumers and producers to embrace services and buying process. This easy transaction is offered by the Internet to grow the business up to higher level. Furthermore, companies can develop creative promotion activities through the Internet which is known as online promotion. The creative and innovative promotion programs through virtual store-fronts and virtual communities could become the competitive advantage for the companies. 
Unlike other traditional media, the Internet is a two-way communication channel that can provide new experiences for consumers. The use of Internet media can assist marketers to more understand consumers, create more effective communication, and offer new services to meet needs and wants of their customers (Chen, J.V. \& Yen, D.C \& Pornpriphet, W. \& Widjaja, 2014; Cravens, D. W., Piercy, N. F., \& Baldauf, 2009; Kresh H., Laible A., Lam M., 2018; Proctor, 2008).

Balerinabeautyshop is a virtual storefront in an online retail shop that provides beauty and health products, gadgets, and fashion applications that are in demand on Indonesian consumers, especially women. The marketing of this company explained that there was a $15 \%$ revenue decrease in April 2015 due to the lower number of online store visitors per day from March (1,100 visitors) to April (900 visitors).

This research used the Analytic Hierarchy Process (AHP) method to identify the problem that was faced by the virtual store-front company. AHP is a qualitative and quantitative approach that involves subjective judgments which are made by decision-makers to evaluate alternatives from several complex criteria into simple hierarchical structures (Chen, M.K. \& Wang, 2010). AHP technique, which is a combination of subjective and quantitative to determine the best combination of attributes that can be used by environmentally friendly refrigerators so that they can support brand equity in the refrigeration industry(Ghodsypour \& O'Brien, 1998). AHP was designed and applied in solving various problems of decision making on various criteria in the field of e-business (Lee, Y. \& Kozar, 2006; Ngai, 2003; Saaty, 1991). AHP has provided views on various outstanding research works (Misra \& Panda, 2017).
While AHP has used in some research on websites and e-business (Lee, Y. \& Kozar, 2006; Ngai, 2003), its linkage with online promotion strategy still gets a less concern. Therefore, this research objective is to design and apply AHP in determining the best online promotion strategy for balerinabeautyshop Company through some steps: analyzing online promotional strategies that have been applied, analyzing the elements (factors, actors, and objectives) which influence promotion strategies for balerinabeautyshop and their level of sensitivity, and finding recommendation of alternative strategies for online promotion which can be applied to maintain the loyalty of the old customers and attract new ones.

\section{Literature Review}

\section{Online Promotion Strategy}

A strategy is an integrated and comprehensive plan for achieving the long-term target by adopting actions and allocating resources in its implementation (Mintzber, 1987) (Jia, F., Orzes, G., Sartor, M., Nassimbeni, 2017). It is determined by the company's objectives integrated with policies, decisions, and various related actions as a whole. Strategies are designed according to the environment and applied to various functional areas of management such as marketing to be effective. Marketing strategies might include pricing, product, promotion, distribution, marketing research, sales, advertising, and merchandising (Proctor, 2008). Those could be applied to build strong relationships with customers through value creation in accordance with their needs and wants. Strategic marketing is the process of strategy development based on needs and wants of the market, the application, and the management of marketing programs to obtain a strategic position and meet customer desires in each target market 
(Cravens, D. W., Piercy, N. F., \& Baldauf, 2009). This research marketing strategy is formulated and implemented based on the marketing mix.

Strategic marketing deals with innovation and marketing mix, including promotion activities. A promotion is the coordination of all initiatives from the seller to create various persuasive information channels in selling goods and services or introducing an idea (Morissan, 2007). Promotion could be special advertising, personal selling, sales promotion, and public relationships that are used to achieve their marketing goals (Kotler \& Armstrong, 2008). Similarly, promotion mix consists of advertising, sales promotion, face-to-face promotion, public relations and direct marketing (Angiopora, 2001; Belch \& Belch, 2001). Thus, properly having maintainable new products and doing the promotion mix would accelerate the success of strategic marketing.

Online promotion is a strategy that is structured and connected to Internet media for the communication activities between producers and consumers. Online promotion utilizes digital media to expand marketing network (Powel, A. $\&$ Matthews, 2006). In addition, every element of the promotion mix is described as integrated marketing communication that plays a special role (Belch \& Belch, 2001). Therefore, the variety of online promotion needs to be geared specifically based on the target consumers to achieve the main marketing objectives, consumers' loyalty, and companies' profit.

\section{Internet Advertising and Electronic Commerce}

Advertising in marketing has the same meaning as the promotion to offer products or introduce new items. Promotion through the Internet for example using search engine marketing
(SEM) or Search Engine Optimizing (SEO) as the channel, is known as online marketing. Businesses should focus on website and app optimization as a myriad sector in today's economy (Kresh H., Laible A., Lam M., 2018). Furthermore, the search engines are acknowledged as Paid Search Advertising (PSA) since the demand for internet users for the services are pumped up. The opportunity of online marketing to become successful is due to the search engine, either the PSA or organic visit.

Promotion plays an essential role in developing business. On the Internet, banner, sponsorship, pop-ups, interstitials, push technologies/webcasting, and links(Turban, Aronson, \& Liang, 2005) have been popular. Moreover, direct sales on the Internet encompass direct mail, database marketing, infomercials, and e-commerce (Belch \& Belch, 2001). Some factors that need to be considered by the company promotion are such as budget, product characteristics, market characteristics, customers, competitor, product lifecycle, and marketing mix (Angiopora, 2001).

Promotion on the Internet channel has a strong relation to e-commerce. Electronic business (e-business) assists users in business activities through the Internet. The existence of electronic banking (ebanking), electronic promotion (epromotion), and electronic commerce (ecommerce) prove that there have been many businesses using the Internet (Oetomo, 2002). Furthermore, ecommerce is the process of exchanging products and services such as buying and selling via computer network including the Internet (Turban et al., 2005). Overall, e-commerce could be any businesses which sell product or service that link consumers, manufacturers, and retailers through Internet provider as the media. 


\section{Method}

Analytic Hierarchy Process (AHP) is a method introduced and developed by Saaty to determine an effective decision through an organized conceptual idea. By using the AHP method, users could give relative values based on complex criteria intuitively by comparative paired (Marimin, 2004). In addition, the basic principal of AHP consists of composing hierarchical, valuing criteria and its alternative, determining priority elements, logical consistently in objects characteristics (Marimin, 2004). The hierarchical system in AHP has not had a rigid procedure to choose the components' system so that the focus of this method is to determine some elements in the hierarchical system that have been already used by the company (Saaty, 1991).

The ballerina beauty shop website, which provided beauty, health, gadgets/PC and fashion products from various suppliers such as Australia, China, Korea and Japan, had five employees working full time and ten people working part-time. The division of the authorities was based on its organizational structure, marketing and Information and Technology (IT) department and was directly under the director of the company. The marketing manager was also responsible for production and packaging.

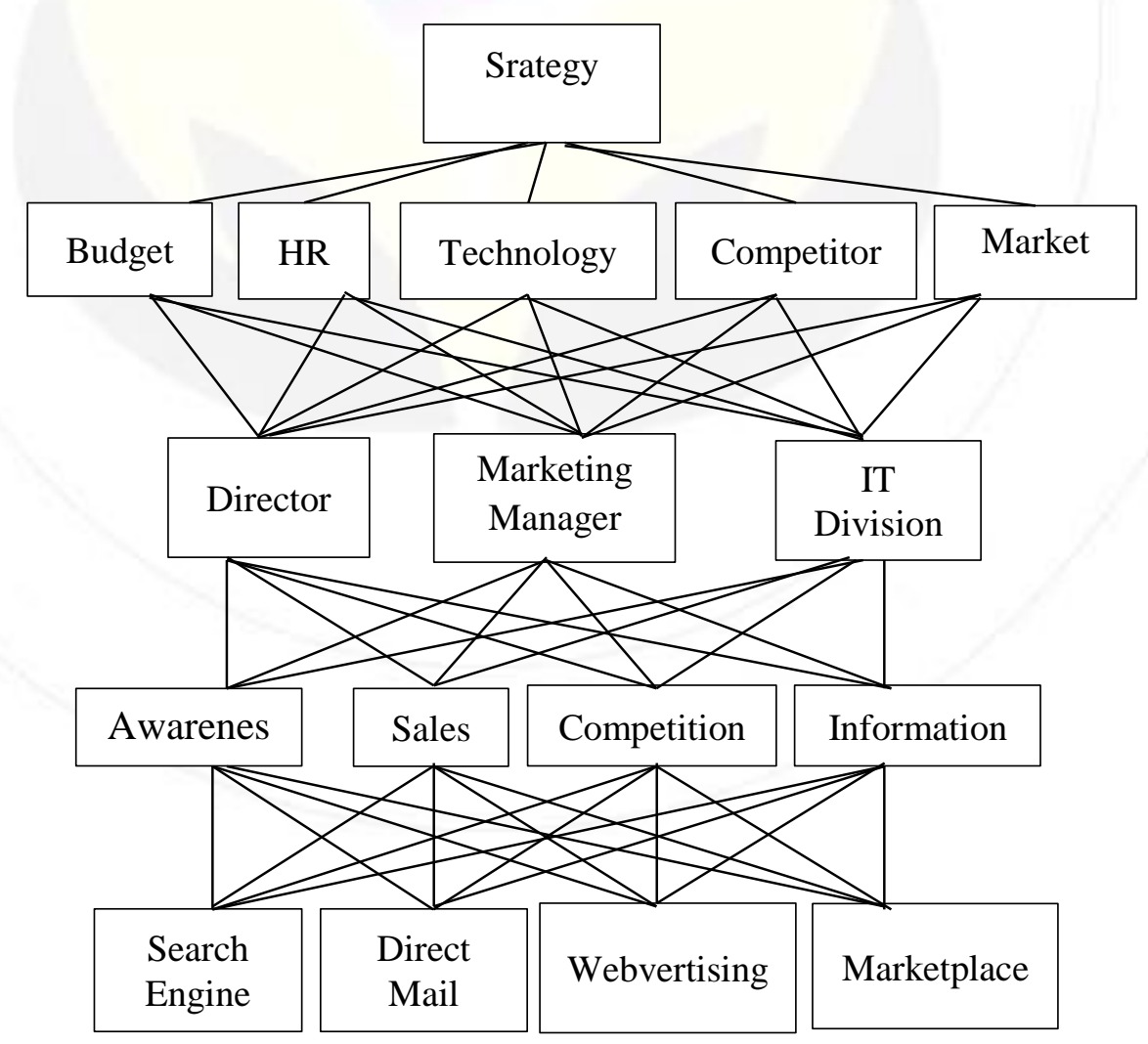

Figure 1. Analytic Hierarchy Process

This research was conducted at the virtual store-front company balerinabeautyshop which had developed its marketing activities through Internet 
media. Analytic Hierarchy Process (AHP) gave an overview of alternative promotion strategy for balerinabeautyshop by using The Expert Choice 11 software which shows the best solution to overcome their problem. The respondents were the actors involved in the preparation of online promotion strategy of balerinabeautyshop consisting of the director, IT department, marketing experts, and representatives of consumer balerinabeautyshop. Data were collected through interview, observation, and questionnaire. Figure 1 shows the structure resulted by analytic hierarchy process to find alternative online promotion strategy.

\section{Result And Discussion}

\section{Online Promotional Strategy}

Balerinabeautyshop is a virtual storefront that had implemented the cost per click as an online promotion strategy for its business. This promotion method collected money from each click made by each visitor on the ad link installed on the website or blog. Advertising through social media is also applied by balerinabeautyshop to get an emotional bond with its previous and prospective customers. Similarly, web pages have been used as the social media in digital marketing since 2017(Kresh H., Laible A., Lam M., 2018).

Based on the information from the marketing department of the company, through social media, the support IT team answered questions which were asked directly by customers. The speed of the team to response affected customers' satisfaction at the balerinabeautyshop. Social media opened opportunities for this business to have direct relationships with their consumers. Promotions, such as product advertising, and special offer brought many advantages which could affect the awareness of target markets and invited feedback from customers through group discussion (Gretzel, U. and Yoo, 2014). In addition, the balerinabeautyshop company actively involved in web discussion groups to make companies easier to do publicity which could cover all levels of online consumers. Companies should be pushed to accommodate a real-time and secure service in their web to keep their consumers' trust (Kresh H., Laible A., Lam M., 2018).

Other marketing strategies that had been implemented by balerinabeautyshop to attract customers to its site was discounted prices for active members or reseller to all products. Technology developments had allowed balerinabeautyshop to make online sales applications through smartphone media to facilitate consumers in making transactions and provide information about product lists to increase consumers' trust in that. Based on a survey to consumers, the top digital marketing techniques were the content marketing, big data, marketing automation, mobile marketing, and social media marketing has the connection to the smartphone (Kresh H., Laible A., Lam M., 2018).

\section{Analytic Hierarchy Process in Online Promotion Strategy}

The Analytic Hierarchy Process (AHP) in this study consisted of four stages (Marimin, 2004). The first was determining the factors that played role in the preparation of the marketing strategy plan for the company. The second stage was identifying actors who had important positions in the strategic making. The third stage was establishing the objectives of the implemented marketing strategies, and the last one was analyzing the alternative strategies to support the marketing strategies that had been implemented. 
Nine factors that make up the promotion strategy for the company are budget, product characteristics, market characteristics, customers, competitors, the product lifecycle stage, technology, human resources, and marketing mix (Angiopora, 2001; Belch \& Belch, 2001). The main promotional factors for the balerinabeautyshop companies included budget, competitors, human resources, technology and markets (Figure 2). While several factors that were considered to be less influential were eliminated.

Actors involved in the preparation of promotional strategies were the company leader, marketing manager, and IT department. Based on the company management team, there were several objectives to be achieved by promotional activities: a) increasing the awareness of the target audience towards the existence of the company, b) increasing sales, c) announcing any latest information from the company to consumers, and d) preparing strategies in facing competitors from similar industries. The results showed that there were four alternative online promotion strategies: search engine optimization, direct mail, marketplace, and webvertising.

Analyzing Elements Criteria, factors, Actors, Goals, and Alternatives for Selection Promotion Strategy

Three stages in this study were done to choose the right decision for the $\begin{array}{lrr}\text { promotion } & \text { strategy } & \text { of } \\ \text { balerinabeautyshop } & \text { through } & \text { a }\end{array}$ comparative matrix. AHP as a tool involving expert thinking has continued to be used and developed in decision making on several criteria(Omkarprasad \& Kumar, 2006). Combining the application of AHP in various fields including numerical addition of AHP (Vargas, 1990) and regulation of activities related to brand equity (Misra \& Panda, 2017).

The matrix set to the link between goal and factors, analyzing the priority and consistency criteria of each factor. Parameter weight is determined through Analytic Hierarchy Process (AHP) (Saaty, 2008) but AHP cannot find contextual relationships in parameters (Kumar et al., 2017). The first step is building a matrix which depicts affiliation goal and factors based on the actors of the online company, balerinabeautyshop.

All elements and alternative promotion strategies which showed on the Table 1 are calculated by the expert choice tool to find out the priority score. The biggest factor that impact on promotion has the highest priority score, which is budget followed by Technology (0.20), Human Resource/HR (0.15), Market (0.16), and Competitor (0.11).

Table 1. Priority actors

\begin{tabular}{ccccccc} 
& Budget & HR & Technology & Competitor & Market & \\
\hline Priority & $\mathbf{0 . 3 7}$ & $\mathbf{0 . 1 5}$ & $\mathbf{0 . 2 0}$ & $\mathbf{0 . 1 1}$ & $\mathbf{0 . 1 6}$ & Priority \\
\hline Director & 0.66 & 0.62 & 0.33 & 0.51 & 0.36 & $\mathbf{0 . 5 3}$ \\
\hline $\begin{array}{c}\text { Marketing } \\
\text { Manager }\end{array}$ & 0.19 & 0.16 & 0.13 & 0.34 & 0.53 & $\mathbf{0 . 2 4}$ \\
\hline $\begin{array}{c}\text { IT } \\
\text { Division }\end{array}$ & 0.15 & 0.23 & 0.54 & 0.15 & 0.11 & $\mathbf{0 . 2 3}$ \\
\hline
\end{tabular}


Table priority actor (Table 1 ) determines the strongest person which valued for developing fit marketing strategy of an online shop. Director is the decision maker and got a great score $(0.53)$. The marketing manager has score 0.24 and IT division has 0.23 . The slight difference between the marketing manager and IT division (0.01) shows that both of them almost have the same proportion in strategy decision.

Table2. Matrix affiliation factors and goal

\begin{tabular}{|c|c|c|c|c|c|c|}
\hline $\begin{array}{c}\text { Item } \\
\text { description }\end{array}$ & Budget & $\begin{array}{c}\text { Human } \\
\text { Resources }\end{array}$ & Technology & Competitor & Market & \\
\hline Budget & 1.00 & 2.61 & 2.17 & 3.11 & 2.04 & \\
\hline $\begin{array}{l}\text { Human } \\
\text { resources }\end{array}$ & 0.38 & 1.00 & 0.73 & 1.75 & 0.80 & \\
\hline Technology & 0.46 & 1.37 & 1.00 & 1.72 & 1.30 & \\
\hline Competitor & 0.32 & 0.57 & 0.58 & 1.00 & 0.80 & \\
\hline Market & 0.49 & 1.25 & 0.77 & 1.25 & 1.00 & \\
\hline \multicolumn{6}{|c|}{ Priority factors } & Priority \\
\hline Budget & 0.38 & 0.38 & 0.41 & 0.35 & 0.34 & 0.37 \\
\hline $\begin{array}{c}\text { Human } \\
\text { resources }\end{array}$ & 0.14 & 0.15 & 0.14 & 0.20 & 0.13 & 0.15 \\
\hline Technology & 0.17 & 0.20 & 0.19 & 0.19 & 0.22 & 0.20 \\
\hline Competitor & 0.12 & 0.08 & 0.11 & 0.11 & 0.13 & 0.11 \\
\hline Market & 0.18 & 0.18 & 0.15 & 0.14 & 0.17 & 0.16 \\
\hline
\end{tabular}

Technology for an online shop is the major part in order to develop online marketing and bear up in the market competition. Next, based on priority score (Table 2), the budget also got the number one position (0.37) and technology $(0.20)$ as the second. To consider that the company tries to focus on the market, the result also shows that the budget produces good affiliation score with competitor and market, that are 3.11 and 2.04 respectively. Meanwhile, technology as the second priority result 1.72 and 1.30 for the affiliation with competitor and marke

Table 3. Matrix affiliation actors and budget

\begin{tabular}{ccccc}
\hline $\begin{array}{c}\text { Item } \\
\text { description }\end{array}$ & Director & $\begin{array}{c}\text { Marketing } \\
\text { Manager }\end{array}$ & $\begin{array}{c}\text { IT } \\
\text { Division }\end{array}$ & \\
\cline { 1 - 4 } Director & 1.00 & 3.73 & $\mathbf{4 . 1 7}$ & \\
\cline { 1 - 3 } $\begin{array}{c}\text { Marketing } \\
\text { Manager }\end{array}$ & 0.27 & 1.00 & 1.40 & \\
\cline { 1 - 4 } IT Division & 0.24 & 0.71 & 1.00 & \\
\cline { 1 - 4 } & Standardized matrix & 0.63 & $\mathbf{0 . 6 6}$ \\
\hline Director & 0.66 & 0.69 & 0.21 & $\mathbf{0 . 1 9}$ \\
\hline $\begin{array}{c}\text { Marketing } \\
\text { Manager }\end{array}$ & 0.18 & 0.18 & 0.18 & $\mathbf{0 . 1 5}$ \\
\hline IT Division & 0.16 & 0.13 & 0.15 &
\end{tabular}


Actors and budget are compared specifically through matrix affiliation actors and budget (Table 3). The main priority for actors is the director $(0.66)$, and the great relation score with IT division show that the director should give more attention to IT division (4.17) to prepared good promotion strategy.

Table 4. Matrix affiliation actors and HR

\begin{tabular}{cccc}
\hline $\begin{array}{c}\text { Item } \\
\text { descript } \\
\text { ion }\end{array}$ & $\begin{array}{c}\text { Direct } \\
\text { or }\end{array}$ & $\begin{array}{c}\text { Marketing } \\
\text { Manager }\end{array}$ & $\begin{array}{c}\text { IT } \\
\text { Divisi } \\
\text { on }\end{array}$ \\
\hline Director & 1.00 & $\mathbf{3 . 8 5}$ & 2.80 \\
\hline $\begin{array}{c}\text { Marketi } \\
\text { ng }\end{array}$ & 0.26 & 1.00 & 0.66 \\
$\begin{array}{c}\text { Manage } \\
\text { r }\end{array}$ & & & \\
\hline $\begin{array}{c}\text { IT } \\
\text { Division }\end{array}$ & 0.36 & 1.51 & 1.00 \\
\hline
\end{tabular}

\begin{tabular}{|c|c|c|c|c|}
\hline \multicolumn{4}{|c|}{ Standardized matrix } & Priori \\
\hline Director & 0.62 & 0.61 & 0.63 & 0.62 \\
\hline $\begin{array}{l}\text { Marketi } \\
\text { ng } \\
\text { Manage }\end{array}$ & 0.16 & 0.16 & 0.15 & 0.16 \\
\hline $\begin{array}{c}\mathrm{r} \\
\mathrm{IT} \\
\text { Division }\end{array}$ & 0.22 & 0.24 & 0.22 & 0.23 \\
\hline
\end{tabular}

Actors and human resource (HR) are compared specifically through matrix affiliation actors and HR (Table 4). The main priority for actors is the director (0.62), but the great relation score is formed between director and marketing manager (3.85). This result is related to the way of company to organize the human resource section. Balerina beauty shop manages more employees under marketing manager.

Table 5. Matrix affiliation actors and technology

\begin{tabular}{|c|c|c|c|c|}
\hline $\begin{array}{c}\text { Item } \\
\text { descript } \\
\text { ion }\end{array}$ & $\begin{array}{l}\text { Direct } \\
\text { or }\end{array}$ & $\begin{array}{c}\text { Marketi } \\
\text { ng } \\
\text { Manager }\end{array}$ & $\begin{array}{c}\text { IT } \\
\text { Divisi } \\
\text { on } \\
\end{array}$ & \\
\hline Director & 1.00 & 2.90 & 0.54 & \\
\hline $\begin{array}{l}\text { Marketi } \\
\text { ng } \\
\text { Manager }\end{array}$ & 0.34 & 1.00 & 0.27 & \\
\hline $\begin{array}{c}\text { IT } \\
\text { Division }\end{array}$ & 1.86 & 3.75 & 1.00 & \\
\hline \multicolumn{4}{|c|}{ Standardized matrix } & $\begin{array}{c}\text { Priori } \\
\text { ty }\end{array}$ \\
\hline Director & 0.31 & 0.38 & 0.30 & 0.33 \\
\hline
\end{tabular}




\begin{tabular}{ccccc}
\hline $\begin{array}{c}\text { Marketi } \\
\text { ng } \\
\text { Manager }\end{array}$ & 0.11 & 0.13 & 0.15 & $\mathbf{0 . 1 3}$ \\
\hline $\begin{array}{c}\text { IT } \\
\text { Division }\end{array}$ & 0.58 & 0.49 & 0.55 & $\mathbf{0 . 5 4}$ \\
\hline \multicolumn{2}{c}{ CR $=0.013$} & & &
\end{tabular}

Actors and technology are compared specifically through the matrix affiliation actors and technology (Table 5). The main priority for actors in this matrix is IT division (0.54), while the director $(0.33)$ is the second priority and the last is marketing manager (0.13). The marketing manager and IT division have resulted in a great score (3.75). That means, for the promotion strategy of online business marketing manager and IT division has a crucial function.

Table 6. Matrix affiliation actors and competitor

\begin{tabular}{|c|c|c|c|c|}
\hline $\begin{array}{c}\text { Item } \\
\text { description }\end{array}$ & Director & $\begin{array}{c}\text { Marketing } \\
\text { Manager }\end{array}$ & $\begin{array}{c}\text { IT } \\
\text { Division }\end{array}$ & \\
\hline Director & 1.00 & 1.51 & 3.31 & \\
\hline $\begin{array}{l}\text { Marketing } \\
\text { Manager }\end{array}$ & 0.66 & 1.00 & 2.37 & \\
\hline IT Division & 0.30 & 0.42 & 1.00 & \\
\hline \multicolumn{4}{|c|}{ Standardized matrix } & Priority \\
\hline Director & 0.51 & 0.52 & 0.50 & 0.51 \\
\hline $\begin{array}{c}\text { Marketing } \\
\text { Manager }\end{array}$ & 0.34 & 0.34 & 0.35 & 0.34 \\
\hline IT Division & 0.15 & 0.14 & 0.15 & 0.15 \\
\hline
\end{tabular}

$$
\mathrm{CR}=0.001
$$

Actors and competitor are compared specifically through matrix affiliation actors and competitor (Table 6). The main priority for actors is a director $(0.51)$, the marketing manager $(0.34)$ is the second priority, and the last is IT division (0.15). The director and IT division collaboration generate the best result (3.31). So that, for the promotion strategy of online business, director and IT division have to plan it together to maintain the business position among competitors. AHP was used for benchmarking (Bauer, Collar, \& Tang, 1992).

Table 7. Matrix affiliation actors and market

\begin{tabular}{|c|c|c|c|c|}
\hline $\begin{array}{c}\text { Item } \\
\text { description }\end{array}$ & Director & $\begin{array}{c}\text { Marketing } \\
\text { Manager }\end{array}$ & $\begin{array}{c}\text { IT } \\
\text { Division }\end{array}$ & \\
\hline Director & 1.00 & 0.66 & 3.24 & \\
\hline $\begin{array}{c}\text { Marketing } \\
\text { Manager }\end{array}$ & 1.51 & 1.00 & 4.44 & \\
\hline IT Division & 0.31 & 0.23 & 1.00 & \\
\hline \multicolumn{4}{|c|}{ Standardized matrix } & Priority \\
\hline Director & 0.35 & 0.35 & 0.37 & 0.36 \\
\hline $\begin{array}{c}\text { Marketing } \\
\text { Manager }\end{array}$ & 0.54 & 0.53 & 0.51 & 0.53 \\
\hline
\end{tabular}




\begin{tabular}{ccccc}
\hline IT Division & 0.11 & 0.12 & 0.12 & $\mathbf{0 . 1 1}$ \\
\hline $\mathrm{CR}=0.001$ & & &
\end{tabular}

Actors and market are compared specifically through matrix affiliation actors and market (Table 7). The main priority for actors is marketing manager (0.53), the director $(0.36)$ is the second priority, and the last is IT division (0.11). The marketing manager and IT division have to do a collaboration to generate the result (4.44) in the matrix. This shows that the promotion strategy in online business could be the best decided by the marketing manager and IT division to reach the market position

Table 8. Objective factors priority

\begin{tabular}{|c|c|c|c|c|}
\hline & Director & $\begin{array}{c}\text { Marketing } \\
\text { Manager }\end{array}$ & $\begin{array}{c}\text { IT } \\
\text { Division }\end{array}$ & \\
\hline Priority & 0.52 & 0.25 & 0.23 & Priority \\
\hline Awareness & 0.11 & 0.09 & 0.16 & 0.12 \\
\hline Sales & 0.60 & 0.58 & 0.48 & 0.57 \\
\hline Competition & 0.17 & 0.21 & 0.13 & 0.17 \\
\hline \multirow[t]{2}{*}{ Information } & 0.12 & 0.12 & 0.23 & 0.15 \\
\hline & 1.00 & 1.00 & 1.00 & \\
\hline
\end{tabular}

Factors which have a link to the objective are analyzed by the expert choice tool to get priority scores (Table 8 ). Sales (0.57) as the main purposes of online business got a big portion of priority. Generally, the business has sales as a substantial target. Priority score results also reveal that awareness (0.12) as the last position in priority of ballerina beauty shop company purpose. Next, competition $(0.17)$ and information (0.15) have an almost similar score, it is, however, important to know that competition could push the company to be more careful in developing a better strategy and resilience in business.

Table 9. Alternative factors priority

\begin{tabular}{cccccc}
\hline & Awareness & Sales & Competition & Information & \\
\hline Priority & 0.12 & 0.57 & 0.17 & 0.15 & Priority \\
\hline $\begin{array}{c}\text { Search } \\
\text { engine }\end{array}$ & 0.40 & 0.24 & 0.26 & 0.41 & $\mathbf{0 . 2 9}$ \\
\hline Direct mail & 0.12 & 0.14 & 0.15 & 0.13 & 0.14 \\
\hline Webvertising & 0.15 & 0.19 & 0.13 & 0.19 & 0.18 \\
\hline Marketplace & 0.34 & 0.43 & 0.46 & 0.26 & $\mathbf{0 . 4 0}$ \\
\hline & 1.00 & 1.00 & 1.00 & 1.00 & \\
\hline
\end{tabular}

Marketplace (0.40) got the highest score in alternative priority analysis (Table 9), nevertheless, the search engine shows that it has a good potential to develop in order to underpin the main alternative marketing strategy of ballerina beauty shop, marketplace. Web advertising and direct mail are the old fashion promotion strategy with priority 0.18 and 0.14 respectively. Although web advertising and direct mail does not get more attention this day, some companies still use those promotion strategies to keep the relationship between the company and its customers.

Table 10. Matrix affiliation alternatives and awareness as objective 


\begin{tabular}{|c|c|c|c|c|c|}
\hline $\begin{array}{l}\text { Item } \\
\text { description }\end{array}$ & $\begin{array}{l}\text { Search } \\
\text { engine }\end{array}$ & $\begin{array}{c}\text { Direct } \\
\text { mail }\end{array}$ & Webvertising & Marketplace & \\
\hline Search engine & 1.00 & 2.12 & 3.02 & 1.78 & \\
\hline Direct mail & 0.47 & 1.00 & 0.49 & 0.28 & \\
\hline Webvertising & 0.33 & 2.03 & 1.00 & 0.32 & \\
\hline Marketplace & 0.56 & 3.54 & 3.14 & 1.00 & \\
\hline \multicolumn{4}{|c|}{ Standardized matrix } & & Priority \\
\hline Search engine & 0.42 & 0.24 & 0.39 & 0.53 & 0.40 \\
\hline Direct mail & 0.20 & 0.12 & 0.06 & 0.08 & 0.12 \\
\hline Webvertising & 0.14 & 0.23 & 0.13 & 0.09 & 0.15 \\
\hline Marketplace & 0.24 & 0.41 & 0.41 & 0.30 & 0.34 \\
\hline
\end{tabular}

If the company try to get more awareness of the customers, it is essential to choose the search engine as an alternative to reach the objective. This statement supported by the highest priority score of analysis result $(0.40)$ for search engine (Table 10). The marketplace as the second option on priority score with 0.34 , has a strong connection with direct mail (3.54) and webvertising (3.14). This similar pattern also seemed as search engine related to direct mail (2.12) and webvertising (3.02).

Table 11. Matrix affiliation alternatives and sales as objective

\begin{tabular}{lcllll}
\hline $\begin{array}{l}\text { Item } \\
\text { description }\end{array}$ & $\begin{array}{c}\text { Search } \\
\text { engine }\end{array}$ & $\begin{array}{l}\text { Direct } \\
\text { mail }\end{array}$ & Webvertising & Marketplace & \\
\cline { 1 - 5 } Search engine & 1.00 & 2.10 & 1.05 & 0.59 & \\
\hline Direct mail & 0.48 & 1.00 & 1.04 & 0.27 & \\
\hline Webvertising & 0.96 & 0.96 & 1.00 & 0.49 & \\
\hline Marketplace & 1.68 & 3.74 & 2.03 & 1.00 & Priority \\
\hline \multicolumn{7}{c}{ Standardized matrix } \\
\cline { 1 - 5 } Search engine & 0.24 & 0.27 & 0.20 & 0.25 & $\mathbf{0 . 2 4}$ \\
\hline Direct mail & 0.12 & 0.13 & 0.20 & 0.11 & 0.14 \\
\hline Webvertising & 0.23 & 0.12 & 0.20 & 0.21 & 0.19 \\
\hline Marketplace & 0.41 & 0.48 & 0.40 & 0.42 & $\mathbf{0 . 4 3}$ \\
\hline
\end{tabular}

$$
\mathrm{CR}=0.02
$$

According to the expert choice for sales as the objective (Table 11), an online company should give more attention to the marketplace as the most potential marketing channel by the priority score of 0.43 . Although search engine for this objective got the second rank in priority score with 0.24 , it plays the same direction with marketplace when resulting a great score combines into direct mail (2.10 and 3.74 respectively). So, there is no doubt that the marketplace and search engine become the alternative marketing strategy for most online companies to be successful in their sales. Anecdotal evidence shows that customers' trust in electronic retailers has advanced recently (Nielsen, 2012).

Table 12. Matrix affiliation alternatives and competition as objective

\begin{tabular}{lcccc}
\hline $\begin{array}{c}\text { Item } \\
\text { description }\end{array}$ & $\begin{array}{c}\text { Search } \\
\text { engine }\end{array}$ & $\begin{array}{c}\text { Direct } \\
\text { mail }\end{array}$ & Webvertising & Marketplace \\
\hline $\begin{array}{l}\text { Search } \\
\text { engine }\end{array}$ & 1.00 & $\mathbf{1 . 2 1}$ & $\mathbf{2 . 4 3}$ & 0.61 \\
\hline Direct mail & 0.82 & 1.00 & 0.84 & 0.26 \\
\hline Webvertising & 0.41 & 1.19 & 1.00 & 0.30
\end{tabular}




\begin{tabular}{lccccc}
\hline Marketplace & 1.63 & $\mathbf{3 . 8 1}$ & $\mathbf{3 . 3 5}$ & 1.00 & \\
\cline { 1 - 5 } & \multicolumn{3}{c}{ Standardized matrix } & & Priority \\
\cline { 1 - 1 } $\begin{array}{l}\text { Search } \\
\text { engine }\end{array}$ & 0.26 & 0.17 & 0.32 & 0.28 & $\mathbf{0 . 2 6}$ \\
\hline Direct mail & 0.21 & 0.14 & 0.11 & 0.12 & 0.15 \\
\hline Webvertising & 0.11 & 0.16 & 0.13 & 0.14 & 0.13 \\
\hline Marketplace & 0.42 & 0.53 & 0.44 & 0.46 & $\mathbf{0 . 4 6}$ \\
\hline \multicolumn{2}{c}{ CR $=0.03$}
\end{tabular}

Analysis of competition as the company's objective (Table 12) shows that marketplace (0.46) has higher score priority than a search engine $(0.26)$. This condition hence promotes marketplace as the most priority alternative for the aim.

Table 13. Matrix affiliation alternatives and information as objective

\begin{tabular}{lcclll}
\hline Item description & $\begin{array}{l}\text { Search } \\
\text { engine }\end{array}$ & $\begin{array}{l}\text { Direct } \\
\text { mail }\end{array}$ & Webvertising & Marketplace & \\
\cline { 1 - 5 } Search engine & 1.00 & $\mathbf{3 . 6 6}$ & 1.43 & 2.17 & \\
\hline Direct mail & 0.27 & 1.00 & 0.94 & 0.37 & \\
\hline Webvertising & 0.70 & 1.06 & 1.00 & 0.66 & \\
\hline Marketplace & 0.46 & $\mathbf{2 . 7 2}$ & 1.50 & 1.00 & Priority \\
\hline \multicolumn{7}{c}{ Standardized matrix } & & $\mathbf{0 . 4 1}$ \\
\hline Search engine & 0.41 & 0.43 & 0.29 & 0.52 & 0.13 \\
\hline Direct mail & 0.11 & 0.12 & 0.19 & 0.09 & 0.19 \\
\hline Webvertising & 0.29 & 0.13 & 0.21 & 0.16 & $\mathbf{0 . 2 6}$ \\
\hline Marketplace & 0.19 & 0.32 & 0.31 & 0.24 & \\
\hline
\end{tabular}

$$
\mathrm{CR}=0.05 \text {. }
$$

The Selection of the Right Promotion Strategy for the Company

The results of processing with AHP showed the priority weights of each element and alternative corporate promotion strategies. Figure 2 shows that the priority factor in the implementation of online promotion strategies is the budget (0.39). As for the actors, the leadership of the company, the marketing manager, and the IT section had a weight of $0.52,0.25$ and 0.23 respectively. The company's lead actor $(0.52)$ showed that it is in the top priority when deciding the company's promotion strategy (Figure 2). The purpose of developing a corporate promotion strategy had the greatest weight on increasing sales (0.57), while the awareness, competition, and
For this objective, both marketplace and search engine have bonded to direct mail and webvertising which described by the great score in affiliation matrix for their relationship. 
context-driven information, reflected the perceived quality of an organization's ecommerce operation (Sharma, G. \& Lijuan, 2015). Therefore, successful ecommerce should be supported by website design ability to reap the benefits of online sales (Sharma, G. \& Lijuan, 2015).

Implementing all of these alternative strategies will give a better influence and bring maximum results to achieve the promotion goals. The marketplace has turned out to be very popular with people in Indonesia and growing rapidly such as Tokopedia, Lazada, and OLX. The quality is an important aspect of both product and distribution channel for ecommerce. Composing the quality in networks systems as a priority strategy is assist e-commerce company to achieve trust, value, reputation, loyalty, and competitive advantage (Torres, J.A.S, \& Arroyo-Cañada, 2017). Similarly, the quality is the important factor in website preference which influences financial performance (Lee, Y. \& Kozar, 2006).

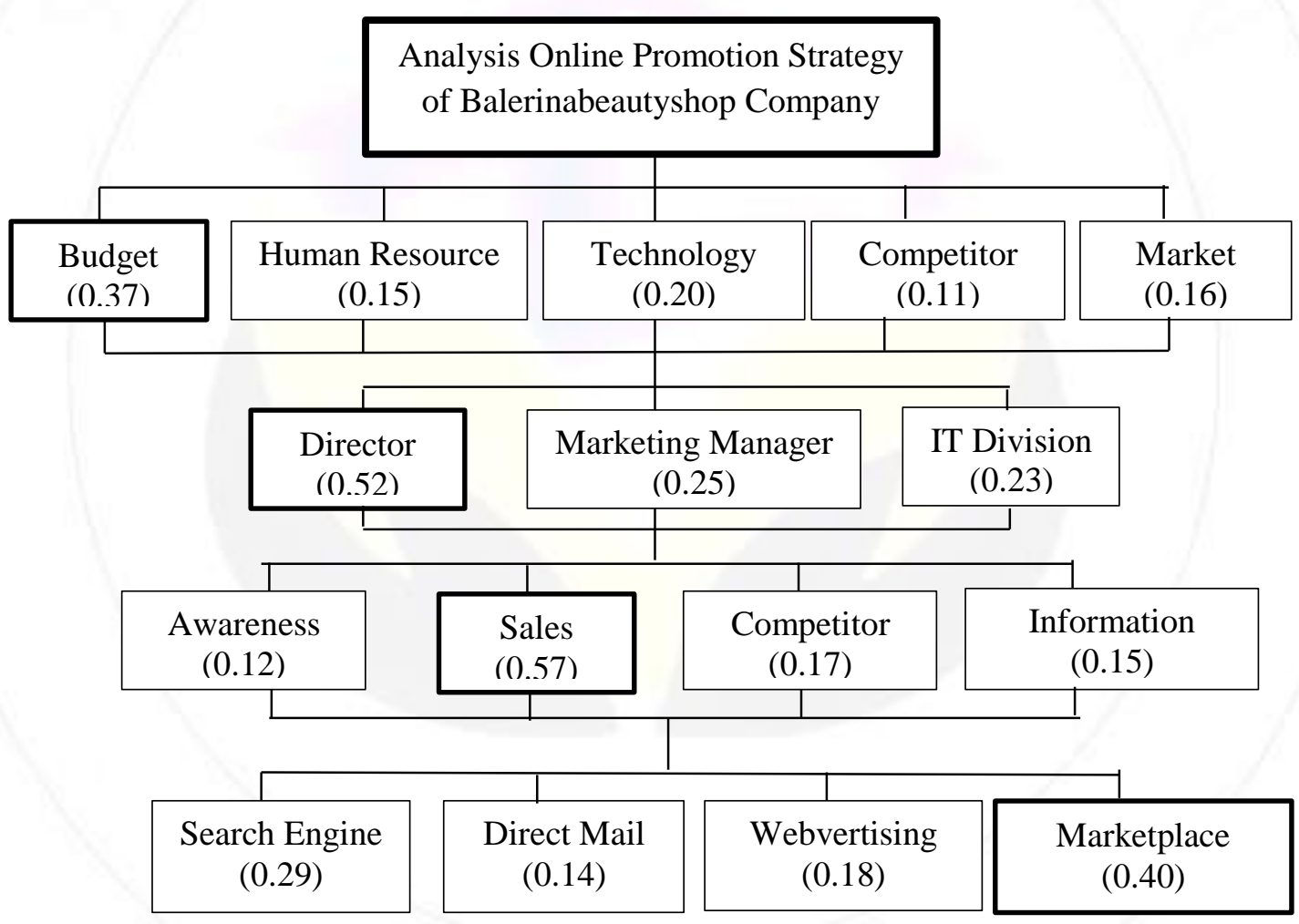

Figure 2. Analytic Hierarchy Process Result

Marketplace in the digital environment is also known as an electronic marketplace. Consumers had different considerations in this marketplace. Although security in the online system should become the crucial factors for e-commerce, marketplaces need to be more proactive to concise the potential buyers and consumers with its online shop (Fu, H., Ho, Y., Chen, R. C.Y., Chang, T., \& Chien, 2006). Three main factors related to e-marketplaces evaluation and selection are the target market determination, dynamic knowledge and expertise in the market, and attractiveness in presenting services and creating values and the relationships (Büyüközkan, 2004).

The quality in digital system embraces some elements, particularly the content of multimedia such as images, moving images (e.g. flash animations or 
stream video), and cute illustrations. The success of electronic business in the world is not solely determined by their employer qualification, but also the cultural differences(Chen, J.V. \& Yen, D.C \& Pornpriphet, W. \& Widjaja, 2014).

\section{Conclusion}

Balerina beauty shop Company applied an online promotion strategy consisting of website promotion with CPC systems (cost per click), price discounts, social media networking, and discussion groups. The most influencer factor is the budget needed in the preparation of the promotion strategy, while the least is the competitor. The most dominant actors in the company for preparing online promotion strategies is the company leader. The aim of the online promotion is to achieve a good level of awareness and sales, provide sufficient information, and survive in competition. The results show that increasing sales is the priority to be achieved by implementing an online promotion strategy.

Based on the Analytic Hierarchy Process (AHP), alternative online promotion strategies through the marketplace got the highest score, which means that the marketplace should be implemented by balerinabeautyshop Company. Technical recommendations for ballerina beauty shop company are to form a more competent IT division and to recruit web experts to carry out tasks related to the management of the shop's website and help the marketing division to conduct online promotions. Online promotion focused on ballerina beauty shop website requires up-to-date content and displays a variety of information that needed based on target consumers (regarding their culture) so that the website can provide integrated, systematic and accurate services.

\section{References}

Angiopora, M. (2001). Dasar-dasar manajemen pemasaran. Jakarta: PT. Raja Grafindo Persada.

Bauer, R. A., Collar, E., \& Tang, V. (1992). The Silverlake project. New York: Oxford University Press.

Belch, G. E., \& Belch, M. A. (2001). An integrated marketing communication perspective. New York: McGraw Hill.

Büyüközkan, G. (2004). Multi-criteria decision making for e-marketplace selection. Internet Research, 14(2), 139-154.

Chen, J.V. \& Yen, D.C \& Pornpriphet, W. \& Widjaja, A. E. (2014). Ecommerce web site loyalty: A cross cultural comparison. Inf Syst Front.

Chen, M.K. \& Wang, S. (2010). The critical factors of success for information service industry in developing international market: Using analytic hierarchy process (AHP) approach. Expert Systems with Applications, 37, 694-704.

Chen, P.-Y., \& Forman, C. (2006). can vendors influence switching costs and compatibility in an environment with open Standards? MIS Quarterly, 30(SI), 541-562.

Cravens, D. W., Piercy, N. F., \& Baldauf, A. (2009). Management framework guiding strategic thinking in rapidly changing markets. Journal of Marketing Management, 25(1-2), 31-49.

Fu, H., Ho, Y., Chen, R. C.Y., Chang, T., \& Chien, P. (2006). Factors affecting the adoption of electronic marketplaces: A fuzzy AHP analysis. International Journal of Operations \& Production Management, 26(12), 1301-1324.

Ghodsypour, S. H., \& O'Brien, C. (1998). A decision support system for supplier selection using an integrated analytical hierarchy process and linear programming. International Journal of Production 
Economics, 56-67(1), 199-212.

Gretzel, U. and Yoo, K. (2014). The Routlege Handbook of Tourism Marketing (pp. 491-504). New York: Routlege.

Jia, F., Orzes, G., Sartor, M., Nassimbeni, G. (2017). Global sourcing strategy and structure: towards a conceptual framework. International Journal of Operations \& Production Management, $37(7)$. https://doi.org/10.1108/ IJOPM-092015-0549.

Kalaignanam, K., Kushwaha, T., \& Rajavi, K. (2018). How Does Web Personalization Create Value for Online Retailers? Lower Cash Flow Volatility or Enhanced Cash Flows. Journal of Retailing, 94(3), 265-279.

https://doi.org/10.1016/j.jretai.201 8.05.001

Kotler, P., \& Armstrong, G. (2008). Prinsip-prinsip Pemasaran. Jakarta: Erlangga.

Kresh H., Laible A., Lam M., R. M. (2018). Online Advertising: Creating a Relationship Between Businesses and Consumers. International Marketing and Management Research.

Kumar, A., Luthra, S., Kumar, D., Mehta, R., Chaudhary, N., \& Bhatia, S. (2017). Measuring and improving customer retention at authorised automobile workshops after free services. Journal of Retailing and Consumer Services, 39(2017), 93102.

https://doi.org/10.1016/j.jretconser. 2017.07.007

Lee, Y. \& Kozar, K. A. (2006). Investigating the effect of website quality on e-business success: An analytic hierarchy process (AHP) approach. Decision Support Systems, 42, 1383-1401.

Marimin. (2004). Teknik dan Aplikasi Pengambilan Keputusan Kriteria Majemuk. Jakarta: Grasindo.
Mat Dangi, M. R., Ismail, A. H., Johari, R. J., \& Md. Noor, R. (2018). SME's Internationalization Initiatives: Business \& Growth Strategy, ICT and Technology. International Journal of Accounting, Finance and Business, 3(12), 63-75.

Mintzber, H. (1987). The Strategy Concept I: Five Ps For Strategy. California Management Review, (Fall).

Misra, S., \& Panda, R. K. (2017). Environmental consciousness and brand equity an impact assessment using analytical hierarchy process (AHP). Marketing Intelligence \& Planning, 35(1), 40-61.

Morissan. (2007). Periklanan dan Komunikasi Pemasaran Terpadu. Jakarta: Ramdina Prakarsa.

Ngai, E. W. . (2003). Selection of web sites for online advertising using the AHP. Information \& Management, 40, 233-242.

Nielsen. (2012). Consumer Trust in Online, Social and Mobile Advertising Grows. Retrieved February 5, 2019, from https://goo.gl/C34AUV

Oetomo, B. S. D. (2002). E-education: Konsep, teknologi dan aplikasi internet pendidikan. Yogyakarta: Andi.

Omkarprasad, S. V., \& Kumar, S. (2006). Analytic hierarchy process: an overview of applications. European Journal of Operational Research, 16(9), 1-29.

Powel, A. \& Matthews, S. (2006). Electrical Conductivity Vigor Test: Physiological Basis and Use. ISTA News Bulletin, 131, 32-35.

Proctor, T. (2008). Strategic marketing: an introduction. London and New York: Routledge.

Saaty, T. L. (1991). Pengambilan Keputusan Bagi Para Pemimpin Proses Hirarki Analitik Untuk Pengambilan Keputusan dalam 
Situasi yang Kompleks. Jakarta: IPPM dan PT. Pustaka Binama Pressindo.

Saaty, T. L. (2008). Decision making with the analytic hierarchy process. Int. J. Serv. Sci, 1(1), 83-98.

Sharma, G. \& Lijuan, W. (2015). The effects of online service quality of e-commerce Websites on user satisfaction. The Electronic Library, 33(3), 468-485.

Sibero, A. (2011). Kitab Suci Web Programing. Yogyakarta: Media Kom.

Torres, J.A.S, \& Arroyo-Cañada, F.

\section{Biographies}

Fatimah Abdillah is a lecturer of Management at STIE Pandu Madania. She has been teaching in management for seven years. She got a master degree in management in 2014. She has concerned her research in marketing, particularly in advertising, tourism, and brand.
(2017). Building brand loyalty in ecommerce of fashion lingerie. Journal of Fashion Marketing and Management: An International Journal, 21(1), 103-114.

Turban, E., Aronson, J. E., \& Liang, T. P. (2005). Decision Support Systems ang Intelligent Systems. Prentice Hall.

Vargas, L. (1990). An overview of analytic hierarchy process: its applications. European Journal of Operational Research, 48(1), 2-8. 